drift, the most fertile part of the plains; water is here plenty in small lakes. The peculiar drainage system of the Andean region is explained chiefly by the Pliocene depression and elevation of a previously dissected mountain range. Glacial erosion is not especially considered as contributing to the present topography. W. M. Davis.

\section{ZOOLOGICAL NOTES.}

DURING the past year, L. Camerano has published (in Atti della R. Accademia delle Scienze di Torino, Vol. XXXV., and Arch. Ital. de Biol, Vol. XXXIII., fasc. 2) papers on the 'somatic coefficient.' These are based on a plea made by Andres that ichthyologists and others express the proportion of parts of the body not in relation to any other convenient organ, as is often done, but rather in thousandths of the total body length. Thus, if $x$ is the proportion to be expressed, $l$ is the observed dimension, and $L$ is the total length of the body, in millimeters, then, $x=\frac{1,000}{L} l$. The factor $\frac{10,000}{L}$ is the somatic coefficient and is constant for all organs of the body. Camerano makes the suggestion that the number 36.0 , being readily divisible by more integers, is preferable to 1,000 and he publishes a convenient table of values of $\frac{360}{L}$ for every quarter unit from 1 to 360 . It is to be hoped, however, that those who express the dimension of organs in multiples of the somatic coefficient will not fail to give also the absolute lengths of the organs, as these are of no less importance.

C. B. D.

IN describing to the Zoological Society of London, on January 15th, the collection of fishes brought home from Lakes Tanganyika and Kivu by the Tanganyika exploring expedition, under the leadership of Mr. J. E. S. Moore, Mr. G. A. Boulenger pointed out that the study of this important collection did not modify the conclusions embodied in his first report published in 1898 . The exploration of Lake Kivu had thrown no light on the origin of the Tanganyikan fauna; the smaller lake proved to be very thinly populated with fishes, which all belonged to widely distributed genera, the species showing a mixture of Nile and Tanganyika elements, with two that might prove to be endemic. The list of the fishes from the two lakes comprised 91 species, 74 of which had been named by the author. The collection now described consisted of examples of 50 species, 26 of which were new to science, 2 being made the types of additional genera of the family Cichlidæ.

\section{A BILL ESTABLISHING A NATIONAL OBSER- VATORY.}

WE are now able to publish the text of the bill introduced into the Senate by Mr. Morgan on January 21st. The provisions seem to be all that could be asked, and it is to be hoped that men of science will unite in urging its passage. Personal letters to members of Congress and resolutions adopted by societies and institutions and forwarded to the Committee on Naval Affairs are the most effective way to advocate the measure. The bill is intended 'to organize the National Observatory of the United States' and reads as follows:

$B e$ it enacted by the Senate and House of Representatives of the United States of America in Congress assembled, That the United States Naval Observatory shall hereafter be known as the National Observatory of the United States, and shall be governed by a Director thereof, who shall report directly to, and be under the supervision of, the Secretary of the Navy.

Secrion 2, That the Director of the National Observatory shall be an eminent astronomer, appointed by the President, by and with the advice and consent of the Senate, at a salary of five thousand dollars per annum, and shall be selected from the astronomers of the National Academy of Sciences unless, in the judgment of the President, an American astronomer of higher scientific and executive qualifications shall be found.

SECTION 3, That the Secretary of the Navy may detail for duty as astronomers at the National Observatory such professors of mathematics and other offcers of the Navy as he shall deem necessary in the interests of the public service; but on and after the 